\title{
Growth, biochemical quality and antioxidant capacity of coriander leaves under organic and inorganic fertilization programs
}

Fereshte Serri ${ }^{1}$, Mohammad Kazem Souri ${ }^{1 *}$ and Mohammadreza Rezapanah ${ }^{2}$

\begin{abstract}
Background: Soil salinity buildup and soil degradation are emerging challenges in cropping systems practicing high chemical fertilization. Application of biostimulants and organic fertilizers are better deserve agricultural sustainability and are generally reflected in more nutritious foods than chemical fertilization.
\end{abstract}

Materials and methods: In this study, the growth, quality and antioxidant capacity of coriander (Coriandrum sativum L.) were evaluated under application of organic and biological compared to chemical fertilization in a pot experiment. Different soil fertilization treatments including vermicompost (20\% pot volume), cow manure (20\% pot volume), biophosphate (as seed inoculation), glycine amino acid (as a biostimulant at $300 \mathrm{mg} / \mathrm{kg}$ soil), mixed NPK fertilizer (at $600 \mathrm{mg} / \mathrm{kg}$ soil) and unfertilized control were applied to plants under a completely randomized design with four replications.

Results: The results showed that application of organic fertilizers mainly vermicompost and glycine, and to lesser extent NPK fertilizer significantly increased many growth, yield and biochemical quality traits of coriander including root and shoot biomass, leaf SPAD value, ascorbic acid, mineral nutrients, flavonoids and antioxidant activity compared to control plants. Fertilization practices resulted in higher biomass production of root (all treatments) and shoot (all treatments except biophosphate) than control plants. Leaf minerals including $\mathrm{N}$ and $\mathrm{K}$ (in vermicompost, NPK and glycine treatments), leaf $\mathrm{P}$ and $\mathrm{Fe}$ (in vermicompost and glycine treatments), leaf $\mathrm{Zn}$ (in vermicompost treatment) were significantly increased compared to control plants. Application of manure recorded the lowest leaf $\mathrm{Ca}$ and total phenols, while the highest leaf Ca was in vermicompost and glycine-treated plants and the highest leaf phenols was in vermicompost treatment. Application of glycine resulted in the highest leaf ascorbic acid as well as catalase enzyme activity. Leaf antioxidant capacity was significantly higher in vermicompost, glycine and NPK treatments compared to control plants. Leaf carotenoids, peroxidase activity, the concentration of $\mathrm{Mg}$, Cu and Mn were not significantly affected by treatments.

Conclusion: The results indicate that cow manure and biophosphate treatments were not much effective on plant growth; however, vermicompost and glycine showed promising improvement of coriander growth and antioxidant capacity even more than NPK fertilization.

Keywords: Amino acid, Antioxidant enzymes, Ascorbic acid, Biophosphate, Glycine, Phenols, Quality, Vegetable, Vermicompost

\footnotetext{
${ }^{*}$ Correspondence: mk.souri@modares.ac.ir

1 Department of Horticultural Sciences, Tarbiat Modares University, Tehran, Iran

Full list of author information is available at the end of the article
}

\section{Background}

Fertilizers are among the most important inputs, either as organic or inorganic, that are applied to increase the production of agricultural crop. Application of inorganic 
fertilizers generally results in rapid and high availability of nutrients to plant roots for a short period $[9,30]$. However, due to their adverse effects on soil fertility in long term, organic fertilizers are preferentially recommended for agricultural applications [1, 13]. Chemical fertilization particularly in intensive cultivation systems has a significant role in environmental pollutions, ecological malfunction, loss of soil fertility, increased soil salinity and degradation, and higher cost of production $[8,19$, 24].

On the other hand, organic agriculture and use of natural and biological fertilizers have been interested as a sustainable approach and remedy to several challenges emerged from intensive or long-term chemical fertilization $[10,30]$. Nowadays, various alternative inputs and cultural practices can be applied to maintain soil fertility and to improve crop mineral nutrition management $[3,12]$. This consequently results in production of safer foods and enhanced consumer and environmental health protections $[8,19]$.

The composted animal manures and mainly vermicompost are still among the most effective organic fertilizers for agricultural production [9, 15, 34]. However, technology can be applied in their processing, compacting and formulation to improve their efficiency, handling and durability [29]. In recent decades, biofertilizers have shown some promising effects on nutrient bioavailability in cropping systems. They are attractive, low cost and environment friendly that alone or in combination with other inorganic or organic fertilizers (as an integrated nutrient management strategy) could play significant role in crops mineral supply $[9,24]$. In agriculture, application of biostimulants can significantly improve plant roots uptake of mineral nutrients [30]. Several studies reported that application of glycine, in soil, nutrient solution or as foliar application can enhance plant growth and quality $[2,17,28]$. Although, application of (glycine) amino acid has not been yet approved in organic culture, however, it can be considered as a safer choice of maintaining soil fertility management than chemical fertilization [32].

Coriander (Coriandrum sativum L.), from Apiaceous family and native to Mediterranean region, is an important leafy vegetable as well as spice crop grown in many countries for its tender green leaves and aromatic fruits $[7,13]$. Organic and healthy production of vegetable crops particularly leafy vegetables such as coriander is quite important. Therefore, this study was aimed to evaluate the growth, quality and antioxidant capacity of coriander plants under different organic fertilizations.

\section{Material and methods \\ Experimental setup}

The study was performed during 2016-2017 and under greenhouse conditions at Faculty of Agriculture, Tarbiat Modares University, Tehran, Iran. Coriander seeds (Coriandrum sativum L.) from a local population (Karaj ecotype) were used in the study. A silty-loamy soil with a moderate level of fertility was prepared. The physiochemical characteristics of soil are presented in Table 1.

\section{Soil preparation}

The soil was disinfected for 4 weeks by solarization before applying treatments, in which the soil was wetted (at $65-70 \%$ of its field capacity) and covered by a thin layer plastic cover, while it was regularly checked and turned over. Thereafter, black plastic pots with volume of $4 \mathrm{~kg}$ dry soil were filled with the soil based on different treatments and then fifty seeds were sown in each pot. After germination and in 3-4 leaves stage, seedlings were thinned to 7 plants per pot. The pots were randomly arranged in a greenhouse with regular changing of their position in every other day. The irrigation of pots was performed daily and by weighing the pots and water addition to $80 \%$ of soil water holding capacity (FC).

\section{Application of treatments}

In this study, different fertilization/biostimulation treatments were applied to pot soil just before or during growth period. The treatments were control (untreated plants), chemical NPK, decomposed cow manure, biophosphate, vermicompost and glycine amino acid applications that were arranged in a completely randomized design with four replications.

The chemical NPK fertilizer (N:20; P:10; K:15) was applied in two splits of a final amount of $600 \mathrm{mg} / \mathrm{kg}$ dry soil. The first half of NPK fertilization was added into the soil at the beginning of experiment (before filling the pots), and the second half was added into the soil via irrigation water and after 3 weeks of germination.

The vermicompost was purchased from Zist Salem Kimia Company, Tehran, Iran, and applied at a rate of $20 \%$ of pot volume, after evenly mixed into the soil before pot filling. The cow manure was first composted for 8 months and then sieved and evenly mixed into the

Table 1 Physicochemical characteristics of soil used in experiment

\begin{tabular}{|c|c|c|c|c|c|c|c|c|c|}
\hline Soil texture & Sand (\%) & Silt (\%) & Clay (\%) & $E C\left(d S m^{-1}\right)$ & $\mathrm{pH}$ & Organic carbon (\%) & Avail. $\mathrm{N}\left(\mathrm{mg} \mathrm{kg}^{-1}\right)$ & Avail. $\mathrm{P}\left(\mathrm{mg} \mathrm{kg}^{-1}\right)$ & Avail. $\mathrm{K}\left(\mathrm{mg} \mathrm{kg}^{-1}\right)$ \\
\hline & 29 & 51 & 19 & 0.49 & 7.15 & 0.45 & 149 & 15.5 & 249 \\
\hline
\end{tabular}


pot soil at a rate of $20 \%$ pot volume. The physiochemical properties of cow manure and vermicompost are presented in Table 2. The biophosphate fertilizer (Barvar 2) was prepared from National Genetic Institute, Tehran, Iran, and contained two species of phosphorus solubilizing bacteria namely Pseudomonas putida (Strain 13) and Pantoea agglomerans (Strain P5). The population of each bacterium was 108 active bacteria per g inoculants. The biophosphate was applied as seed inoculation before sowing and under dark conditions. Seeds were inoculated for $30 \mathrm{~min}$ in a solution of $1 \mathrm{~g}$ biophosphate to $10 \mathrm{~mL}$ distilled water. The seeds were then dried in shadow and thereafter were sown in pot soil. Glycine amino acid was applied to pots in two split applications (each $150 \mathrm{mg} / \mathrm{kg}$ soil) after emergence and with a 2-week interval in a final concentration of $300 \mathrm{mg} / \mathrm{kg}$ soil. For this purpose, the amino acid was dissolved in distilled water and applied to pots. Plants were grown for 7 weeks after emergence and different plant growth parameters including morphophysiological traits, enzymes and nutrient uptake characteristics were determined.

\section{Measurements}

The different plant growth traits were measured during growth period or at harvest or after plant harvesting. Plant height was recorded using a caliper and leaf SPAD value (the Soil and Plant Analysis Development) was determined by average of 30 readings of plant (middle) leaves per pot using SPAD meter (model 502 Plus, Illinois, USA). At harvest the plants were cut at soil surface and their roots were gently washed out of soil particles and blotted dry against tissue paper. Plant shoot and root fresh weights, as well as their dry weights (after oven drying at 65 for $48 \mathrm{~h}$ ) were determined using a digital balance. L-ascorbic acid concentration of leaves was determined using dichlorophenol indophenols method proposed by Souri et al. [28] with a modification. $10 \mathrm{~g}$ of leaf materials were manually crushed in mortar with $10 \mathrm{~mL}$ metaphosphoric acid $6 \%$, thereafter the mixture was centrifuged at $9000 \mathrm{rpm}$ for $10 \mathrm{~min}$ at $4{ }^{\circ} \mathrm{C}$. Five $\mathrm{mL}$ of supernatant was diluted to $10 \mathrm{~mL}$ using $5 \mathrm{~mL}$ metaphosphoric acid $2 \%$ and the solution was titrated using dichlorophenol indophenols $0.2 \mathrm{mM}$. The amounts of L-ascorbic acid of leaf samples were calculated from consumed reagent, and after calibration of the method using different concentrations of standard L-ascorbic acid. Leaf carotenoids were determined using acetone extraction of $0.5 \mathrm{~g}$ of fresh leaf tissues by a spectrophotometer following the method proposed by Kałużewicz et al. (2018). Determination of leaf flavonoids and total phenols followed the methods used by Ferreira et al. [10]. Leaf mineral nutrient concentrations were determined with different methods, nitrogen using Kjeldahl, potassium using flame photometric method, phosphorus using spectrophotometric method, calcium, magnesium, iron, zinc, manganese and copper using atomic absorption spectrometer. Leaf antioxidant capacity was determined by scavenging 1,1-diphenyl-2-picrylhydrazyl (DPPH) radical following the methods described by BrandWilliams et al. [6]. Samples of leaf extract $(200 \mu \mathrm{L})$ were mixed with $3 \mathrm{~mL}$ of $0.0525 \mathrm{mM} \mathrm{DPPH}$ in full ethanol. Decrease in absorbance of samples was monitored every $1 \mathrm{~min}$ for $30 \mathrm{~min}$ at $517 \mathrm{~nm}$ using a Perkin-Elmer Lambda $25 \mathrm{UV} / \mathrm{Vis}$ spectrophotometer. The radicalscavenging capacity of the samples was considered as percentage inhibition of DPPH.

Determination of catalase enzyme activity (CAT) was followed Pereira et al. [21]. Briefly, the assay solution contained $50 \mathrm{mM}$ phosphate buffer $(\mathrm{pH} 7.5)$ and $25 \mathrm{mM} \mathrm{H}_{2} \mathrm{O}_{2}$ in cool conditions. The process started with adding $0.1 \mathrm{~mL}$ of protein enzyme extract to reaction medium. CAT activity was assayed by monitoring a decrease in the absorbance of $\mathrm{H}_{2} \mathrm{O}_{2}$ within 1 min at $240 \mathrm{~nm}$ and $25^{\circ} \mathrm{C}$. The amount of enzyme activity was expressed as unit $\mu \mathrm{g}^{-1} \mathrm{Pr}$. For determination of peroxidase activity $4 \mathrm{mM}$ acetate buffer $0.4 \mathrm{M}$ (pH 5), $4 \mathrm{mM}$ $\mathrm{H}_{2} \mathrm{O}_{2} 3 \%$ and $0.2 \mathrm{~mL}$ benzidine $2 \%$ in methanol $50 \%$ were added to each tube while placed in ice, and finally $0.2 \mathrm{~mL}$ of protein enzymatic extract was added to each tube. The absorbance change was read at $530 \mathrm{~nm}$, and the amount of enzyme activity was determined as unit $\mu \mathrm{gPr}^{-1}$ following Pereira et al. [21].

\section{Statistical analysis}

The data were analyzed using Software SPSS (SPSS Inc., Chicago IL), and comparison of means were done using Duncan's multiple range test at $5 \%$ level.

Table 2 Chemical properties of cow manure and vermicompost used in the study

\begin{tabular}{lllllll}
\hline & pH & EC $\left(\mathbf{d S ~ m}^{\mathbf{- 1}}\right)$ & $\begin{array}{l}\text { Organic carbon } \\
(\%)\end{array}$ & Nitrogen (\%) & Phosphorus (\%) & Potassium (\%) \\
\hline Manure & 8.95 & 4.32 & 48 & 1.10 & 0.29 & 1.89 \\
Vermicompost & 4.65 & 7.96 & 35 & 1.15 & 1.1 & 1.3 \\
\hline
\end{tabular}




\section{Results and discussion}

The obtained results showed that some growth parameters of coriander plants were significantly influenced by fertilization treatments. The effects of treatments on fresh and dry weights of shoots and roots, and leaf characteristics of SPAD value, flavonoids, L-ascorbic acid (vitamin $\mathrm{C}$ ), nitrogen and antioxidant capacity were significant at $P \leq 0.01$, and on leaf phenols, catalase activity and potassium, phosphorus, calcium, iron and zinc were significant at $P \leq 0.05$. However, the treatments effects on leaf concentration of carotenoids, magnesium, copper, manganese and peroxidase activity were not significant.

Application of NPK fertilizer, vermicompost and glycine significantly increased leaf SPAD value (Table 3) compared to control plants, and leaf SPAD was significantly higher in vermicompost than other treatments. Shoot fresh and dry weights (Table 3) were significantly increased in all fertilization treatments except in biophosphate treatment compared to control plants. The highest shoot biomass was recorded in NPK and vermicompost treatments that showed no difference with glycine treatment. All fertilization treatments significantly increased the plant root fresh and dry weights (Table 3) compared to control plants. However, application of NPK, glycine, manure, vermicompost and biophosphate were the most to the least treatments effective in root fresh weight increase, respectively. The difference in root dry weight (Table 3) among fertilization treatments was less than root fresh weight.

The increase in biomass production is a common plant response to fertilization particularly under limited soil minerals availability (Karmegam et al. [4]. We observed that vermicompost was the most effective treatment to enhance the plant growth and biomass production. Vermicompost is a well-known effective organic and biological fertilizer that can improve plant growth more than chemical fertilization $[25,33]$. The use of different organic and biological fertilizers including vermicompost increased the growth characteristics of basil including plant height, and roots and shoots biomass [18]. The higher growth promotion by application of vermicompost could be due to higher availability of minerals, and the presence of various biostimulants including organic acids, amino acids, enzymes and plant hormones $[15,16$, 26]. Our results showed that glycine was the most effective treatment after vermicompost to improve coriander growth. The biostimulation effect of glycine amino acid to enhance plant growth has been also reported [17]. Glycine can interact with unavailable soil minerals to make them more accessible to plant roots [30]. In addition, application of glycine has been shown to increase plant root growth that further can support plant growth [2].

The concentration of leaf flavonoids (Table 3) was significantly higher under NPK, vermicompost and glycine treatments compared to control and other treatments. There was no significant difference in leaf flavonoids among manure, biophosphate and control-treated plants. Leaf total phenols (Table 3) were significantly higher in vermicompost-treated plants only compared to manure treatment that showed the lowest amount. In this sense, it is remarkable that flavonoids and phenols represent significant biochemical compounds and strong antioxidants in plant cells $[10,20]$. The influence of fertilization practices on leaf flavonoids and phenolics has been previously reported $[12,18]$. In fennel plants, phenolic compounds and antioxidants were significantly increased by application of different organic fertilizers [5]. It is well known that abiotic stresses such as drought, salinity and minerals deficiency can enhance production of some biochemical compounds including phenols and flavonoids [26, 27]. Plants, based on their genetic and climatic factors, have an inherent capacity to produce and accumulate a given compound such as flavonoids [16].

Table 3 Physiological and biochemical traits of coriander under fertilization treatments

\begin{tabular}{|c|c|c|c|c|c|c|c|}
\hline Treatments & $\begin{array}{l}\text { Leaf SPAD } \\
\text { values }\end{array}$ & $\begin{array}{l}\text { Shoot FW (g/ } \\
\text { pot) }\end{array}$ & Root FW (g/pot) & $\begin{array}{l}\text { Shoot DW (g/ } \\
\text { pot) }\end{array}$ & Root DW (g/pot) & $\begin{array}{l}\text { Leaf flavonoids } \\
\text { (mg/100 g FW) }\end{array}$ & $\begin{array}{l}\text { Leaf total } \\
\text { phenols (mg } \\
\text { GAE/g FW) }\end{array}$ \\
\hline Control & $11.8 \mathrm{c}$ & $13.3 c$ & $19.8 d$ & $1.50 c$ & $1.95 c$ & $4.2 b$ & $1.1 \mathrm{ab}$ \\
\hline NPK fertilizer & $16.6 b$ & $24.2 \mathrm{a}$ & $81.1 \mathrm{a}$ & $3.26 a$ & $6.33 a$ & $6.3 a$ & $1.2 \mathrm{ab}$ \\
\hline Manure & $15.5 b c$ & $17.7 b$ & 73.4ab & $2.36 b$ & $5.89 a$ & $4.9 b$ & $0.9 b$ \\
\hline Vermicompost & $20.7 a$ & $22.3 a b$ & $68.2 \mathrm{bc}$ & $3.20 \mathrm{a}$ & $5.84 a$ & $6.8 a$ & $1.3 a$ \\
\hline Biophosphate & $12.6 \mathrm{bc}$ & $12.7 c$ & $57.5 c$ & $1.53 c$ & $4.07 b$ & $4.7 b$ & $1.0 \mathrm{ab}$ \\
\hline Glycine & $16.2 b$ & 20.0ab & 78.6ab & $2.83 a b$ & 5.30ab & $6.6 a$ & $1.2 \mathrm{ab}$ \\
\hline P value & $* *$ & $* *$ & $* *$ & $* *$ & $* *$ & $* *$ & $*$ \\
\hline
\end{tabular}

** and * mean significant treatments effect at $1 \%$ and $5 \%$ level, respectively

The means with at least one common letter are not statistically different at $5 \%$ level of Duncan's multiple range test 
Nevertheless, our results showed that the production of flavonoids and phenols was optimized by application of vermicompost, glycine and NPK fertilization.

Application of treatments significantly influenced the concentration of L-ascorbic acid (vitamin C) of leaves (Fig. 1). Plants treated with glycine, vermicompost and NPK fertilizer showed significantly higher leaf ascorbic acid compared to control plants; as the significant highest leaf ascorbic acid was registered in plants treated with glycine, but reflecting no difference with vermicompost treatment. There was no difference in leaf ascorbic acid among control, manure and biophosphate treatments. Ascorbic acid as a water-soluble compound represents one of the main quality factors of vegetables as well as an antioxidant compounds in plant cells $[2,10]$. The influence of chemical or organic fertilization on ascorbic acid enhancement of plant products was reported elsewhere $[14,32]$. The coriander leaf ascorbic acid was mainly enhanced by glycine and then vermicompost and NPK.
The amount of this vitamin in plant tissues, regardless of genetic differences, can be maximum under optimum leaf water status and photosynthesis [30]. It was suggested that amino acids such as glycine can enhance soil minerals and water uptake and leaf photosynthesis resulting in improved biochemical and antioxidant profile of plants [32]. In fennel (Foeniculum vulgare Mill.) application of organic and biological fertilizers significantly increased (almost doubled) the amount of leaf vitamin C [5].

The leaf $\mathrm{N}$ (Table 4) was significantly higher in plants treated with NPK, vermicompost and glycine treatments compared to control and other treatments, detecting the lowest with manure treatment, which reflected no difference with the control or biophosphate treatment. Similarly, the leaf K (Table 4) was significantly higher in NPK, vermicompost and glycine treatments compared to control or manure treatment that showed the lowest value. The increase in leaf P by NPK application was not statistically significant; but application of vermicompost and

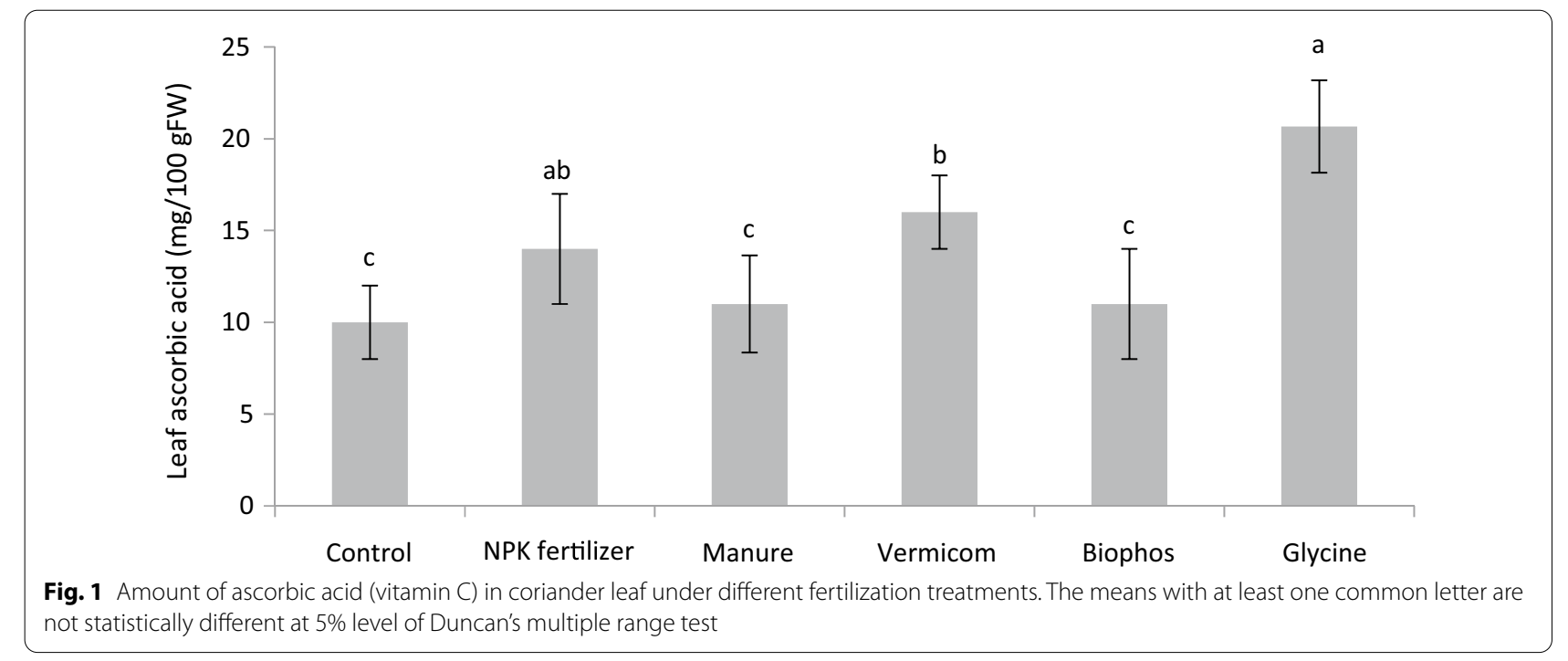

Table 4 Leaf mineral concentrations of coriander under different fertilization treatments

\begin{tabular}{|c|c|c|c|c|c|c|}
\hline Treatments & Leaf $\mathrm{N}(\% \mathrm{DW})$ & Leaf K (\% DW) & Leaf $\mathrm{P}(\% \mathrm{DW})$ & Leaf Ca (\% DW) & $\begin{array}{l}\text { Leaf Fe }(\mathrm{mg} / \mathrm{kg} \\
\text { DW) }\end{array}$ & $\begin{array}{l}\text { Leaf } \mathrm{Zn} \\
(\mathrm{mg} / \mathrm{kg} \\
\mathrm{DW})\end{array}$ \\
\hline Control & $2.0 \mathrm{~b}$ & $1.6 a b$ & $0.26 b$ & $1.97 \mathrm{~b}$ & $44.2 \mathrm{~b}$ & $33.1 b$ \\
\hline NPK fertilizer & $2.7 a$ & $2.0 \mathrm{a}$ & $0.30 \mathrm{ab}$ & $2.13 a b$ & $43.1 \mathrm{~b}$ & $34.5 b$ \\
\hline Manure & $1.8 \mathrm{~b}$ & $1.6 b$ & $0.27 b$ & $1.47 c$ & $50.2 a b$ & $37.3 a b$ \\
\hline Vermicompost & $2.8 a$ & $2.1 \mathrm{a}$ & $0.37 a$ & $2.63 a$ & $56.6 \mathrm{a}$ & $44.8 \mathrm{a}$ \\
\hline Biophosphate & $2.1 \mathrm{~b}$ & $1.8 \mathrm{ab}$ & $0.26 b$ & $1.77 b c$ & $45.7 b$ & $35.3 b$ \\
\hline Glycine & $2.6 a$ & $2.2 \mathrm{a}$ & $0.35 a$ & $2.5 a$ & $59.3 a$ & $42.7 a b$ \\
\hline$P$ value & $* *$ & * & * & * & * & * \\
\hline
\end{tabular}

** and * mean significant treatments effect at $1 \%$ and $5 \%$ level, respectively

The means with at least one common letter are not statistically different at $5 \%$ level of Duncan's multiple range test 
glycine significantly increased leaf P compared to control plants. Plants treated with vermicompost and glycine evidenced the highest leaf concentration of $\mathrm{Ca}$, showing significant difference only with manure treatment. Moreover, leaf Fe (by vermicompost and glycine) and Zn (by vermicompost) were significantly increased compared to control plants (Table 4), while a non-significant increase in leaf $\mathrm{Zn}$ (with manure and glycine treatments) or leaf Fe (with manure) compared to control plants were also noticed.

Application of chemical or organic fertilizers can influence the uptake of minerals by plant roots [26]. Our results suggest that application of vermicompost and glycine resulted in better elemental profile of coriander leaves compared to NPK fertilization. This indicates that the soil physiochemical and biological status (affected by organic fertilizers) is more important than just minerals addition such as NPK fertilization [30]. We found that application of vermicompost was the most effective treatment on coriander minerals uptake. Vermicompost has generally a high level of available minerals as well as other growth promoting compounds [22, 24, 25]. Different compounds such as organic acids, amino acids, peptides and enzymes as well as plant growth regulators that are released from decomposition of organic matter or earthworm, may individually or collectively result in enhanced plant growth and minerals uptake by vermicompost application [9, 34]. On the other hand, biostimulation and chelating effects of glycine amino acid has been suggested to enhance root growth and minerals uptake particularly under restricted soil conditions [32]. In addition, amino acids such as glycine have semi-hormonal effects that can further promote plant growth [30].

The results showed that application of glycine resulted in highest leaf catalase enzyme activity while the lowest activity was recorded in vermicompost treatment (Fig. 2). On the other hand, leaf peroxidase activity (in range of

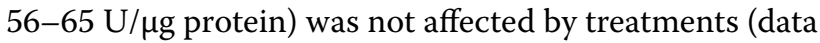
not shown). Leaf antioxidant capacity was significantly increased in vermicompost, glycine and NPK treatments compared to control plants. There was no significant difference in leaf antioxidant capacity among biophosphate, manure and control plants (Fig. 3).

Application of organic fertilizers (vermicompost and glycine) and NPK increased the antioxidant capacity of coriander leaves that was mainly associated with increase in antioxidant compounds rather than antioxidant enzymes. Enhanced biochemical profile and antioxidant capacity of plants has been also well documented under organic fertilization (Kazimierczak et al., 2008). The foods from organic agriculture or those produced with organic fertilizers have generally higher antioxidant capacity than foods produced with chemical fertilization and conventional farming $[10,14,20]$. The highest leaf catalase activity in glycine-treated plants probably is due to some stress signaling under glycine application [30]. The stressful effects of high concentration of amino acids including glycine have been also reported [32]. Catalase is an important antioxidant enzyme involved in cell protection and scavenging of free radicles that generally are produced in routine biochemical processes and particularly under stress conditions [12, 21].

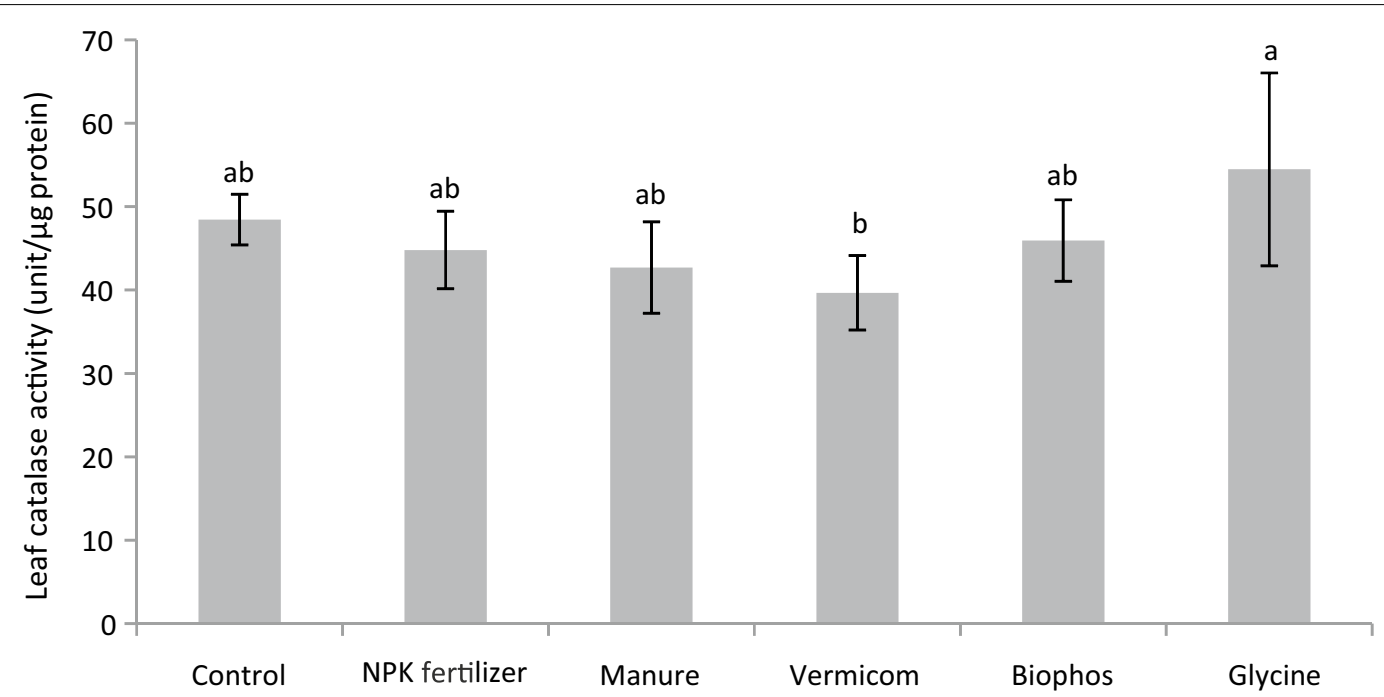

Fig. 2 Activity of catalase enzyme in coriander leaves under different fertilization treatments. The means with at least one common letter are not statistically different at 5\% level of Duncan's multiple range test 


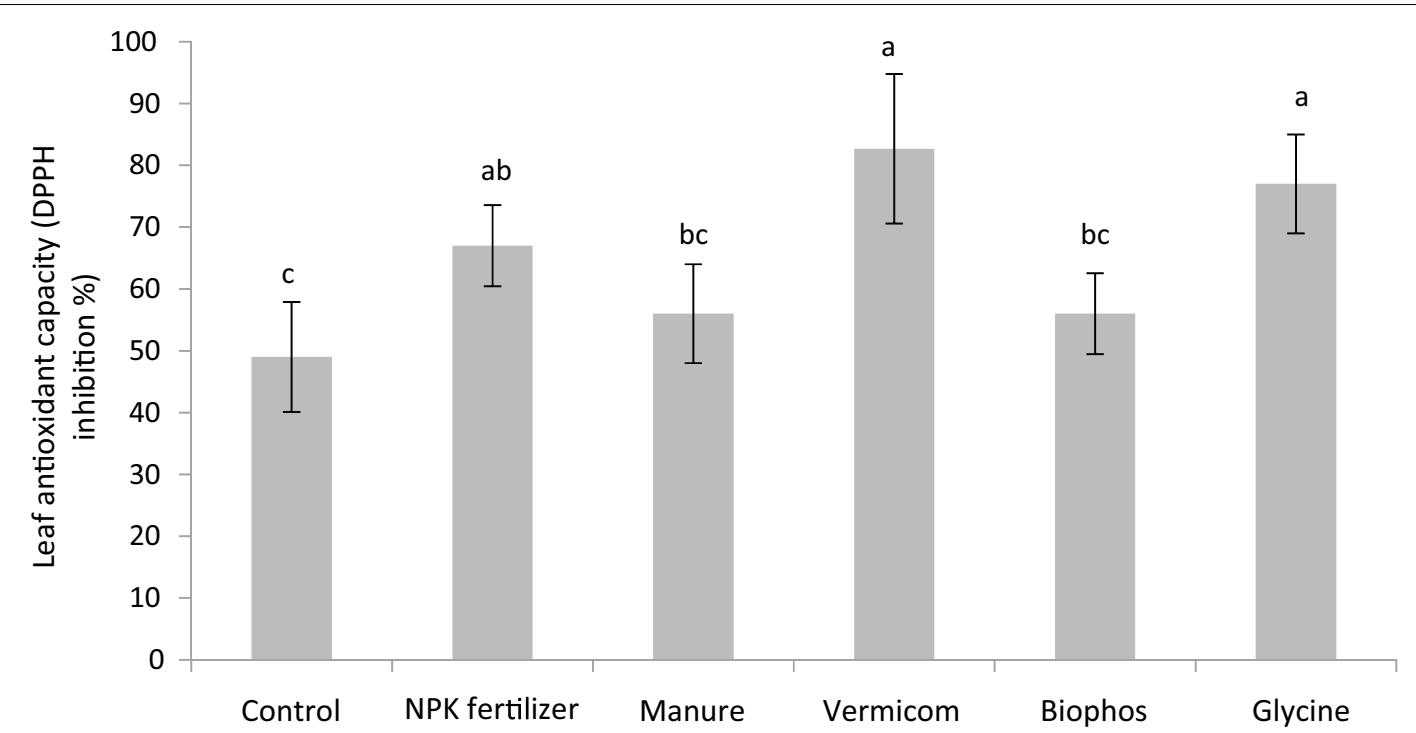

Fig. 3 Leaf antioxidant capacity of coriander plants under different fertilization treatments. The means with at least one common letter are not statistically different at $5 \%$ level of Duncan's multiple range test

In this study, fertilization treatments reflected significant effects on coriander growth traits, as vermicompost, glycine and to lesser extent NPK fertilization recorded the best growth, quality and antioxidant capacity of the plants. On the other hand, the plant growth and quality were not affected by application of cow manure or biophosphate treatments. In this study, the soil had a silty-loam texture with a moderate level of fertility; so, under these conditions with relatively low N (149 mg/kg soil available nitrogen), the application of composted cow manure resulted in lowest benefits compared to control plants. However, manure-treated plants produced higher root biomass compared to control plants, probably as a result of temporally $\mathrm{N}$ deficiency [31] due to microbial immobilization following manure addition [16, 29]. Similar to manure treatment, biophosphate was not effective on coriander growth except root biomass, probably due to restriction in microbial establishment in the soil during active plant growth $[16,18]$. Nevertheless, our findings confirm that plants grown with organic fertilizers were nutritionally superior than those produced with inorganic fertilizers, however, this superiority and benefits of organic fertilizers depend highly on soil fertility level and forms of applied organic fertilizer.

\section{Conclusion}

Application of organic fertilizers mainly vermicompost and glycine were the best among all treatments to enhance the growth and biochemical quality characteristics of coriander plants including leaf greenness, antioxidant capacity and minerals content. Chemical
NPK treatment also increased coriander growth characteristics, but to lesser extent than vermicompost and glycine treatments. The composted cow manure and biophosphate were not able to significantly improve coriander growth, while application of glycine resulted in the highest leaf vitamin $\mathrm{C}$, root biomass and catalase enzyme activity, corresponding to $40 \%, 36 \%$ and $12 \%$ increase than control plants, respectively. The results indicate that coriander as a leafy vegetable with a short growth period can be benefitted from organic fertilizers such as vermicompost and application of growth stimulants such as glycine amino acid, even more than NPK fertilization.

\section{Abbreviations}

NPK: Nitrogen, phosphorous, potassium mix fertilizer; SPAD: The Soil and Plant Analysis Development; FW: Fresh weight; DW: Dry weight; CAT: Catalase; DPPH: Diphenyl-2-picrylhydrazyl.

\section{Acknowledgements}

Not applicable.

\section{Authors' contributions}

MKS designed and supervised the experiment. FS performed the greenhouse and laboratory workloads and wrote the first manuscript draft. MKS analyzed the data. MRP gave scientific advice and practical laboratory helps. All authors revised and edited the manuscript. All authors read and approved the final manuscript.

\section{Funding}

This research did not receive any specific grant from funding agencies in the public, commercial, or not-for-profit sectors.

Availability of data and materials

Are available on request. 


\section{Declarations}

Ethics approval and consent to participate

All authors listed have contributed significantly to the work and agree to be in the author list.

\section{Consent for publication}

All authors agree to publish the work.

\section{Competing interests}

The authors declare no competing interest.

\section{Author details}

'Department of Horticultural Sciences, Tarbiat Modares University, Tehran, Iran. ${ }^{2}$ Iranian Research Institute of Plant Protection, Tehran, Iran.

Received: 28 December 2020 Accepted: 8 May 2021

Published online: 07 July 2021

\section{References}

1. Aćimović MG. The influence of fertilization on yield of caraway, anise and coriander in organic agriculture. J Agric Sci. 2013;58(2):85-94.

2. Aghaye Noroozlo Y, Souri MK, Delshad M. Effects of soil application of amino acids, ammonium, and nitrate on nutrient accumulation and growth characteristics of sweet basil. Commun Soil Sci Plant Anal. 2019:50(22):2864-72.

3. Amodio ML, Colelli G, Hasey JK, Kader AA. A comparative study of composition and postharvest performance of organically and conventionally grown kiwifruits. J Sci Food Agric. 2007;87(7):1228-36.

4. Angeli KP, Delazari FT, Nick C, Ferreria MG, da Silva DJ. Yield components and water use efficiency in coriander under irrigation and nitrogen fertilization. Revista Brasileira de Engenharia Agrícola e Ambiental. 2016:20(5):415-20.

5. Badawi MA, Abou El-Magd MM, Hassan HA, El-Shakry MFZ. Effect of biofertilization, nitrogen sources, nitrogen levels and their interaction on the vegetative growth, chemical content and oil yield of sweet fennel. Egypt J Appl Sci. 2005:20:567-91.

6. Brand-Williams W, Cuvelier ME, Berset CLWT. Use of a free radical method to evaluate antioxidant activity. LWT-Food Sci Technol. 1995;28(1):25-30

7. Carrubba A. Organic and chemical N fertilization on coriander (Coriandrum sativum L.) in a Mediterranean environment. Indus Crops Prod. 2014;57:174-87.

8. Citak S, Sonmez S. Effects of conventional and organic fertilization on spinach (Spinacea oleracea L.) growth, yield, vitamin C and nitrate concentration during two successive seasons. Sci Hortic. 2010:44:415-20.

9. Dinani ET, Asghari HR, Gholami A, Masoumi A. Replacement of vermicompost for nitrogen fertilizer as a source of nitrogen on two cultivars of coriander (Coriandrum sativum). Acta Hortic. 2014;1018:343-9.

10. Ferreira VB, Silva TTC, Couto SRM, Srur AUOS. Total phenolic compounds and antioxidant activity of organic vegetables consumed in Brazil. Food Nutr Sci. 2015;6:798-804.

11. Jaipaul Sharma S, Dixit AK, Sharma AK. Growth and yield of capsicum (Capsicum annuum L.) and garden pea (Pisum sativum L.) influenced by organic manures and biofertilizers. Indian J Agri Sci. 2011:81(7):637-42.

12. Knap M, Ogrinc N, Potocnik K, Vidrih R. Antioxidant activity in selected Slovenian organic and conventional crops. Acta Agri Slovenica. 2014;103(2):281-9.

13. Lal G, Ravindra S. Comprehensive evaluation of coriander (Coriandrum sativum) varieties under different organic modules. Indian J Agri Sci. 2016;86(1):31-6.

14. Leclerc J. Vitamin and mineral contents of carrot and celeriac grown under mineral or organic fertilization. Biologic Agri Hortic. 1991:74:339-48.
15. Maji D, Misra P, Singh S, Kalra A. Humic acid rich vermicompost promotes plant growth by improving microbial community structure of soil as well as root nodulation and mycorrhizal colonization in the roots of Pisum sativum. Appl Soil Ecol. 2017;110:97-108.

16. Marschner P. Marschner's mineral nutrition of higher plants. 3rd ed. London: Elsevier; 2011.

17. Mosa WF, Ali HM, Abdelsalam NR. The utilization of tryptophan and glycine amino acids as safe alternatives to chemical fertilizers in apple orchards. Environ Sci Pollut Res. 2020:28:1-9.

18. Naiji M, Souri MK. Nutritional value and mineral concentrations of sweet basil under organic compared to chemical fertilization. Hortorum Cultus. 2018;17(2):167175.

19. Oates $L$, Cohen M. Human consumption of agricultural toxicants from organic and conventional food. J Org Syst. 2009:4(1):48-57.

20. Pandey KB, Rizvi SI. Plant polyphenols as dietary antioxidants in human health and disease. Oxid Med Cell Longev. 2009;2(5):270-8.

21. Pereira GJG, Molina SMG, Lea PJ, Azevedo R. Activity of antioxidant enzymes in response to cadmium in Crotalaria juncea. Plant Soil. 2002;239(1):123-32.

22. Rai R, Thapa U, Mandal AR, Roy B. Growth, yield and quality of cabbage (Brassica oleraceae var capitata L.) as influenced by vermicompost. Environ Ecol. 2013;31(1A):314-7.

23. Rzekanowski C, Marynowska K, Rolbiecki S, Rolbiecki R. Effect of irrigation and nitrogen fertilization on the yield of coriander [Coriandrum sativum L.]. Herba Polonica. 2007;3(53).

24. Sakthivel P, Sujeetha AR, Ravi G, Girish AG, Chander P. Effect of vermicompost with microbial bio inoculums on the growth parameter of coriander (Coriandrum sativum L.). Int J Curr Microbiol App Sci. 2020;9(8):613-22.

25. Sanwal RC, Sharma Y. Impact of vermicompost, nitrogen and phosphorus on yield, quality and uptake of coriander (Coriandrum sativum L.) under arid condition. IJCS. 2017;5(6):1698-702.

26. Singh $M$. Effect of vermicompost and chemical fertilizers on growth, yield and quality of coriander (Coriandrum sativum L.) in a semi-arid tropical climate. J Spices Aromat Crops. 2011;20(1):30-3.

27. Singh M, Guleria N. Influence of harvesting stage and inorganic and organic fertilizers on yield and oil composition of (Rosmarinus officinalis L.) in a semi-arid tropical climate. Ind Crops Prod. 2013:42:37-40.

28. Souri MK, Naiji M, Aslani M. Effect of Fe-glycine aminochelate on pod quality and iron concentrations of Bean (Phaseolus vulgaris L.) under lime soil conditions. Commun Soil Sci Plant Anal. 2018;49(2):215-24.

29. Souri MK, Naiji M, Kianmehr MH. Nitrogen release dynamics of a slow release urea pellet and its effect on growth, yield, and nutrient uptake of sweet basil (Ocimum basilicum L.). J Plant Nutr. 2019;42(6):604-14.

30. Souri MK, Hatamian M. Aminochelates in plant nutrition; a review. J Plant Nutr. 2019;42(1):67-78.

31. Wang D, Shi Q, Wang X, Wei M, Hu J, Liu J, Yang F. Influence of cow manure vermicompost on the growth, metabolite contents, and antioxidant activities of Chinese cabbage (Brassica campestris ssp. chinensis). Biol Fertil Soils. 2010;46(7):689-96.

32. Zargar Shooshtari F, Souri MK, Hasandokht MR, Kalate JS. Glycine mitigates fertilizer requirements of agricultural crops: case study with cucumber as a high fertilizer demanding crop. Chemic Biol Technol Agric. 2020;7(1):1-10.

33. Zhang N, Ren YL, Shi QH, Wang XF, Wei M, Yang FJ. Effects of vermicompost on quality and yield of watermelon. China Veget. 2011;6:76-9.

34. Zhongqi HE, Pagliari PH, Waldrip HM. Applied and environmental chemistry of animal manure: a review. Pedosphere. 2016;26(6):779-816.

\section{Publisher's Note}

Springer Nature remains neutral with regard to jurisdictional claims in published maps and institutional affiliations. 